\title{
Suitability of Current and Future Conditions to Apiculture in Egypt using Geographical Information System
}

\author{
Hossam F. Abou-Shaara ${ }^{1}$
}

\begin{tabular}{|c|c|}
\hline I N F O & A B S T R A C T \\
\hline \multicolumn{2}{|l|}{ Received 15 May 2015} \\
\hline Accepted 27 Jun 2015 & Apiculture is currently considered as an important economic activity in Egypt. Most \\
\hline Available on-line 29 Jun 2015 & agricultural areas in Egypt are located close to Nile river as well as apicultural activities. \\
\hline Responsible Editor: M. Herdon & $\begin{array}{l}\text { Recently, various desert areas have been widely reclaimed and inhabited. In this study, } \\
\text { the land suitability to apiculture in Egypt, either cultivated or desert areas, was }\end{array}$ \\
\hline Keywords: & investigated using geographical information system (GIS), under current and future \\
\hline $\begin{array}{l}\text { Apiculture, GIS, Egypt, honey } \\
\text { bees. }\end{array}$ & $\begin{array}{l}\text { conditions (2070). Two maps were extracted from the spatial analysis; one map for } \\
\text { current conditions and the second one for future conditions. The study shows that most }\end{array}$ \\
\hline & Egypt is suitable for apiculture but the more suitable areas are restricted to specific \\
\hline & $\begin{array}{l}\text { locations. In the future, land suitability was found to be impacted by future conditions, } \\
\text { mainly thermal stress. Upper Egypt will be greatly impacted than the middle or north }\end{array}$ \\
\hline & Egypt. Apiaries relocation is advisable especially at upper Egypt when necessary during \\
\hline & $\begin{array}{l}\text { 2070. It could be expected that apiculture could be practiced widely throughout Egypt } \\
\text { currently and in the future as well, and in reclaimed lands. The spatial analysis was done } \\
\text { using the major factors that could impact beekeeping; namely, maximum and minimum } \\
\text { temperatures, precipitation, slope, land type, and distance from plants. }\end{array}$ \\
\hline
\end{tabular}

\section{Introduction}

Apiculture (beekeeping) has special importance to the agricultural sector in Egypt, and is increased actively every year. Most beekeepers depend mainly on the products of honey bee colonies as source of income. Because the development of honey bee colonies requires good vegetation, most apicultural activities is existed close to cultivated areas along the Nile River. It is known that the main food for honey bees is nectar (Nicolson 2008) and pollen (Huang 2012) collected from flowering plants. It could be said beekeeping in Egypt depends mainly on three flowering plants; citrus, clover and cotton (Hussein 2001). These plants are not available in all Egyptian governorates, hence, beekeepers usually transport their colonies from region to another to follow the flowering season. Apart from these main plants, honey bee colonies, in general, should be placed near to cultivated plants to get their feeding requirements. Placing honey bee colonies in barren lands could lead to the death of the colonies. Recently, desert reclamation is being done actively in Egypt (Abou-Shaara 2013a). It could be expected that apicultural activities can be greatly done in these regions. Hence, the first objective of this study is to identify the potential areas at which apiculture can be successfully practiced in Egypt including lands with desert nature.

To realize this objective, geographical information system (GIS) can be considered as a proper way. GIS was used previously to achieve somewhat similar objectives; e.g. rangeland suitability for beekeeping (Amiri \& Shariff 2012), suitable wintering sites for honey bee colonies (Abou-Shaara 2013b), and to identify the suitable locations for using modified beehives in Saudi Arabia (AbouShaara et al. 2013a), and for other purposes related to honey bees (see, Myung-Hee et al. 2001; Coulson et al. 2005). GIS has a good ability to analyze different datasets and to present the results on maps with geographical nature, even if these datasets are related to honey bee morphology (AbouShaara 2013c). Honey bee colonies are impacted by many factors including; temperature, precipitation, slope, land cover and distance from plants (e.g. Amiri et al. 2011; Amiri \& Shariff 2012;

\footnotetext{
${ }^{1}$ Hossam F. Abou-Shaara

Department of Plant Protection, Faculty of Agriculture, Damanhour University, P.O.Box 22516, Damanhour, Egypt.

e-mail: entomology_20802000@yahoo.com
} 
Abou-Shaara et al. 2013b). These factors have special importance to honey bees because they can greatly impact all the activities of honey bee colonies. For example, temperature is very important for brood rearing and development (Petz et al. 2004 \& Tautz et al. 2003) and foraging activity (BlazyteCereskiene et al. 2010) while vegetation is very important as source of food to honey bee colonies even at desert areas (Zaitoun \& Vorwohl 2003).

Nowadays, climate change is considered to be the main future challenge to apiculture (Yoruk \& Sahinler 2013). Climate change can impact honey bee colonies directly (Le Conte \& Navajas 2008), or indirectly by impacting flowering plants (Rader et al. 2013). Expecting the potential impacts of climate change on land suitability to apiculture is very important to help decision makers to take the right actions in the proper times. Therefore, the second objective of this study is to identify the potential areas at which apiculture can be successfully practiced in the future, and to compare it with the suitability map of current conditions. To achieve this objective, the available future temperatures and precipitation, beside slope, land cover and distance from plants were incorporated into the GIS spatial analysis to obtain the future suitability map. In light of this study proper recommendations for beekeepers are presented.

\section{Methodology}

\subsection{Study location}

The study was performed to cover all Egyptian governorates, representing a total area of about 1 million square kilometers. Egypt is located in northwest Africa between longitudes of $25^{\circ}$ and $35^{\circ} \mathrm{E}$, and latitudes of $22^{\circ}$ and $32^{\circ} \mathrm{N}$. Very few areas are with high altitude of more than $835 \mathrm{~m}$ above sea level while the most areas have altitude less than $218 \mathrm{~m}$, (Figure 1).

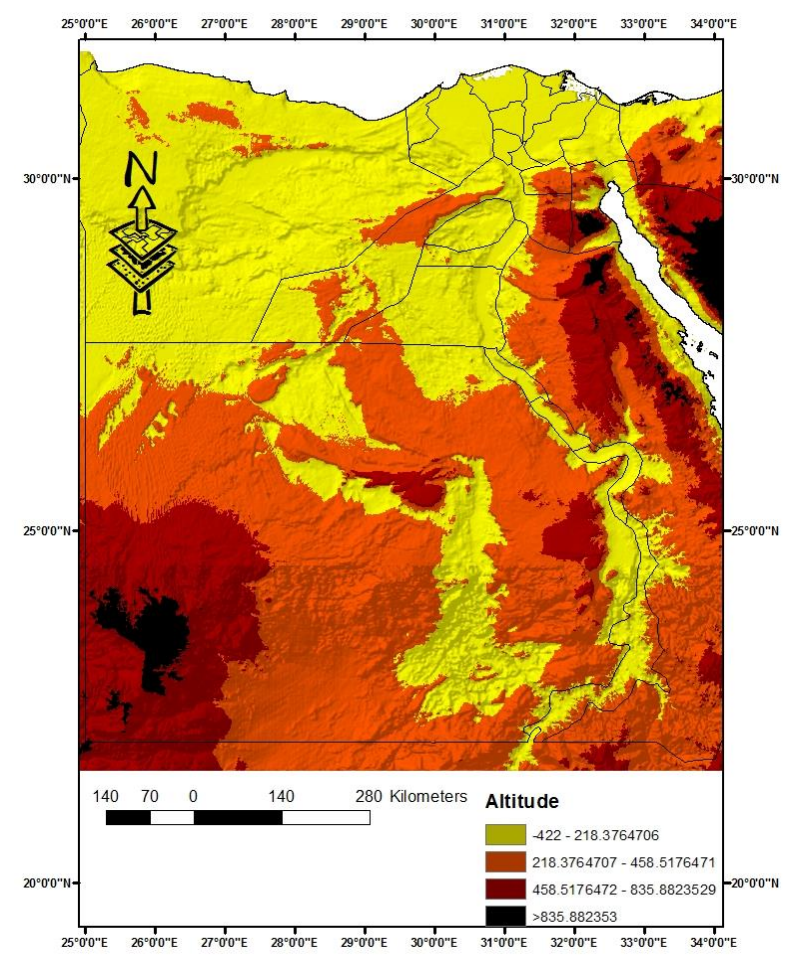

Figure 1. Map of Egypt shows the altitude.

\subsection{Land suitability to apiculture}

The land suitability to apiculture was identified using GIS spatial analysis. ArcGIS 10 was used to perform the analysis. Factors incorporated into the study were selected based on previous investigations of Amiri et al. (2011), Amiri and Shariff (2012), Abou-Shaara (2013b) and AbouShaara et al. (2013b). Apiculture is impacted mainly by some factors more than others (namely, maximum temperature, minimum temperature, land cover, distance from plants, precipitation during winter, and slope). Layers of the studied factors were obtained from DIVA-GIS.com for land cover 
and elevation, and from Worldclim.com for temperature and precipitation. Presented limits in Table 1 of studied factors were assigned according mainly to the work of Abou-Shaara (2013b) and AbouShaara, et al. (2013b). Land cover data as grid and with resolution of 30 seconds were used to create the land cover layer. All land cover types were considered as artificial lands and classified as unsuitable, except vegetation (cultivated area) which was classified as more suitable to apiculture. To extract distance from plants layer, the land cover layer was saved as raster layer, and then Euclidean distance from cultivated plants expressed as units was calculated using spatial analyst tools. Slope was calculated using elevation map with resolution of 30 seconds using surface tools from spatial analyst tools menu of the ArcGIS.

Layers of maximum and minimum temperatures, and precipitation were downloaded as ESRI grid (raster) format from Worldclim.com, and then these layers were classified as shown in Table1 and saved as raster layers. Investigated factors were classified into three categories; more suitable, suitable or unsuitable to apiculture. The more suitable regions have temperature from 10 to $37^{\circ} \mathrm{C}$ throughout the year, winter precipitation less than 30, land with slope less than 7 degrees, and should be near to cultivated areas. These parameters were selected to ensure that honey bee colonies will not be under any environmental stress, and in accordance with previous studies. It has been found that very low temperature below $10^{\circ} \mathrm{C}$ can hinder foraging activity (Joshi and Joshi, 2010) as well as very high temperature (Al-Qarni 2006 \& Blazyte-Cereskiene et al. 2010). The high winter precipitation prevents worker foraging to gather food as reviewed by Abou-Shaara (2014). The uneven land or land with few plants is not suitable to establish apiaries in them (Abou-Shaara 2013b). The acceptable limits with few impacts on honey bees were considered as suitable while the completely unacceptable conditions were considered as unsuitable as shown in Table 1, including artificial lands, lands with very high slope or lands located far from plants, and regions with very high or very low temperatures. Because range of maximum and minimum temperatures differed from season to another, seasonal temperatures were incorporated into the spatial analysis individually. The maximum temperature during spring and fall as well as minimum temperature during summer were not included into the analysis because their ranges were found to be suitable to honey bees (from 10 to $37.9^{\circ} \mathrm{C}$ ), and it was not possible to classify their ranges into different suitability degrees.

Table 1. Limits and suitability degree for used temperatures, land cover, distance from plants, slope and precipitation in GIS spatial analysis.

\begin{tabular}{lcl}
\hline Factors (range) & Limits & Suitability Degree \\
\hline Winter temperature. & $>10$ & More Suitable \\
$\begin{array}{l}\text { Minimum temp. }\left(-3.7-14.8^{\circ} \mathrm{C}\right) \\
\text { Maximum temp. }\left(6.7-26.3^{\circ} \mathrm{C}\right)\end{array}$ & $<10$ & Unsuitable \\
\hline $\begin{array}{l}\text { Spring temperature. } \\
\text { Minimum temp. }\left(2.5-19.3^{\circ} \mathrm{C}\right)\end{array}$ & $>10$ & More Suitable \\
\hline $\begin{array}{l}\text { Summer temperature. } \\
\text { Maximum temp. }\left(21.4-40.3^{\circ} \mathrm{C}\right)\end{array}$ & $>37$ & Unsuitable \\
\hline Fall temperature. & $>10$ & More Suitable \\
Minimum temp. $\left(-4.8-26.9^{\circ} \mathrm{C}\right)$ & $<10$ & Unsuitable \\
\hline & Cultivated lands & More Suitable \\
\hline Land cover (types) & Artificial lands & Unsuitable \\
\hline & $0-0.3$ & Unsuitable \\
\hline $\begin{array}{l}\text { Distance from plants }(\text { units }) \\
\text { (0-3.26) }\end{array}$ & $0.3-0.6$ & More Suitable \\
\hline
\end{tabular}




\begin{tabular}{lcl}
\hline Precipitation-winter. & $<30$ & More Suitable \\
$(0-44 \mathrm{~mm})$ & $>30$ & Suitable \\
\hline & $0-7$ & More Suitable \\
\hline Slope (degrees) & $7-16$ & Suitable \\
\hline & $>16$ & Unsuitable \\
\hline
\end{tabular}

To obtain the final suitability map, after classifying the prepared layers of studied factors into different classes, the layers were combined together using raster calculator tool. All the layers were combined at the same weight in accordance with Abou-Shaara et al. (2013b), because all the layers have the same importance in regard to identify suitable apiary locations. To validate the used model, random locations were selected from different governorates in Egypt and were compared by real images of Google Earth to ensure their suitable location to apiculture (e.g. close to cultivated areas).

\subsection{Land suitability to apiculture in the future (2070)}

Datasets of maximum and minimum temperatures, and winter precipitation during 2070 (representing means of 2061 to 2080) were obtained from global climate models of Beijing climate center_climate system model (BCC_CSM1.1), using representative concentration pathways 45 (rcp 45). These future conditions were incorporated into the spatial analysis as shown in Table 2, beside the previously mentioned factors (namely; slope, land cover type, and distance from plants, these layers were used typically as mentioned in Table1). Only minimum temperature during summer was considered as suitable to all regions with range from 13.1 to $29.5^{\circ} \mathrm{C}$, thus it was not included into the analysis. Datasets were combined at the same weight to all factors to obtain the final suitability map. Suitability maps of current and future conditions were compared to identify potential future changes.

Table 2. Maximum and minimum temperatures, and precipitation during 2070, their limits and suitability degree used in the GIS analysis.

\begin{tabular}{lcl}
\hline Factors (range) & Limits & Suitability Degree \\
\hline Winter temperature. & $>10$ & More Suitable \\
Minimum temp. $\left(-15.7-16.8^{\circ} \mathrm{C}\right)$ & $<10$ & Unsuitable \\
Maximum temp. $\left(9.3-28.3^{\circ} \mathrm{C}\right)$ & & \\
\hline Spring temperature. & $>10$ & More Suitable \\
Minimum temp. $\left(5.2-21.9^{\circ} \mathrm{C}\right)$ & $<10$ & Unsuitable \\
\hline Summer temperature. & $<37$ & More Suitable \\
Maximum temp. $\left(26.1-45^{\circ} \mathrm{C}\right)$ & $>37$ & Unsuitable \\
\hline Fall temperature. & $>10$ & More Suitable \\
Minimum temp. $\left(7.6-25.4^{\circ} \mathrm{C}\right)$ & $<10$ & Unsuitable \\
\hline Spring and Fall. & $<37$ & More Suitable \\
Maximum temp. $\left(19.2-39^{\circ} \mathrm{C}\right)$ & $>37$ & Unsuitable \\
\hline Precipitation-winter. & $<30$ & More Suitable \\
\hline (0-44.67 mm) & $>30$ & Suitable \\
\hline
\end{tabular}




\section{Results and Discussion}

\subsection{Land suitability to apiculture}

As shown in Figure 2, the more suitable locations for apiaries are existed near to Nile River where the cultivated areas are existed. In Egypt, agriculture depends on Nile River as the main source for irrigation, and relatively few cultivated areas are existed in deserts as shown in Figure 3. The map (Figure 2) shows that many locations were classified as suitable to apiculture in desert areas. These locations were likely classified as suitable and not as more suitable due to the absence of cultivated areas (vegetation). The desert regions were, in general, classified as unsuitable, mostly because high slope, and the absence of cultivated areas beside the unsuitable climatic conditions according to the used factors in the spatial analysis.

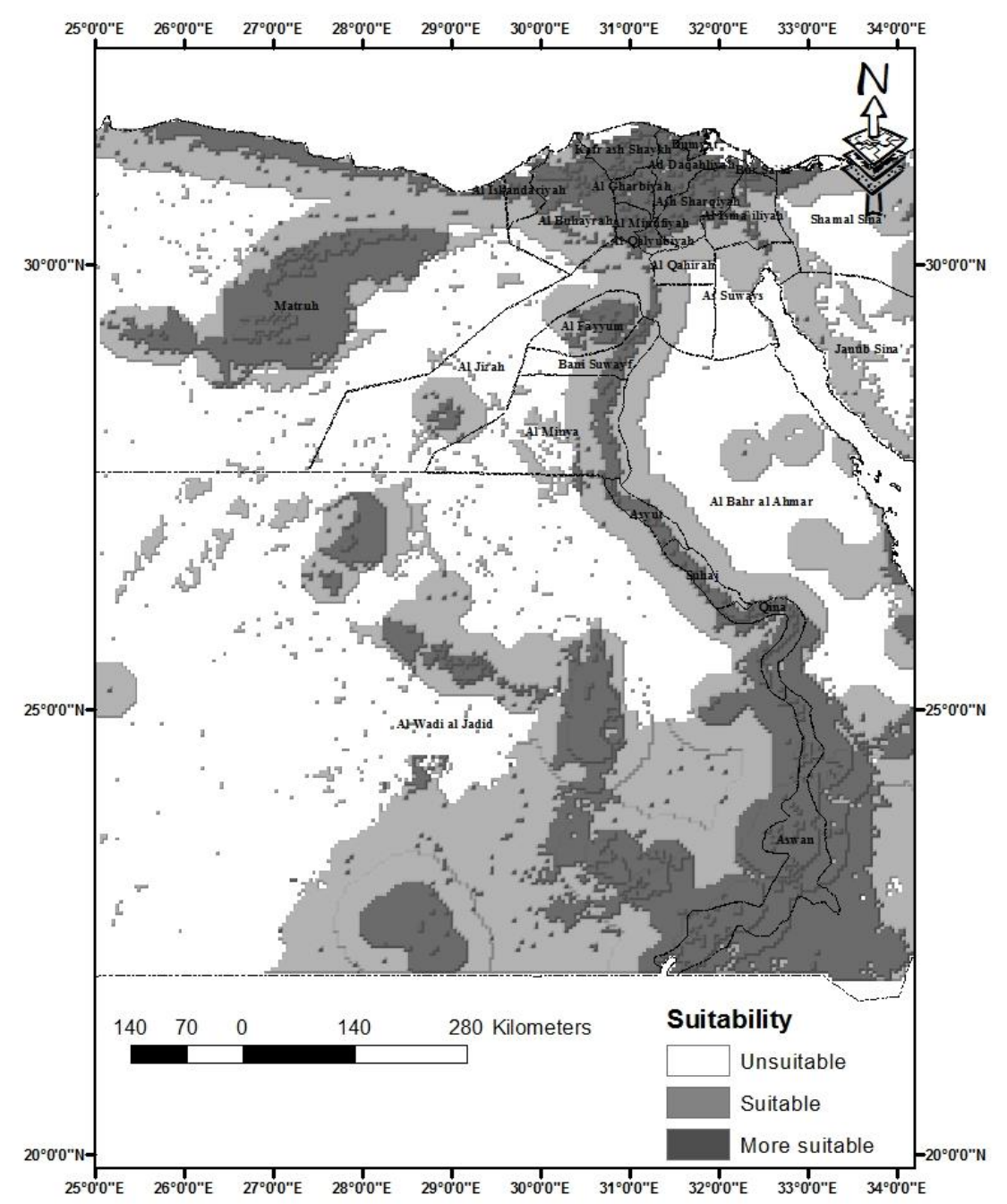

Figure 2. Suitability map for apiary locations under current conditions.

Figure 3. Approximate vegetation map to Egypt, all other things except plants in this map were classified as artificial. 


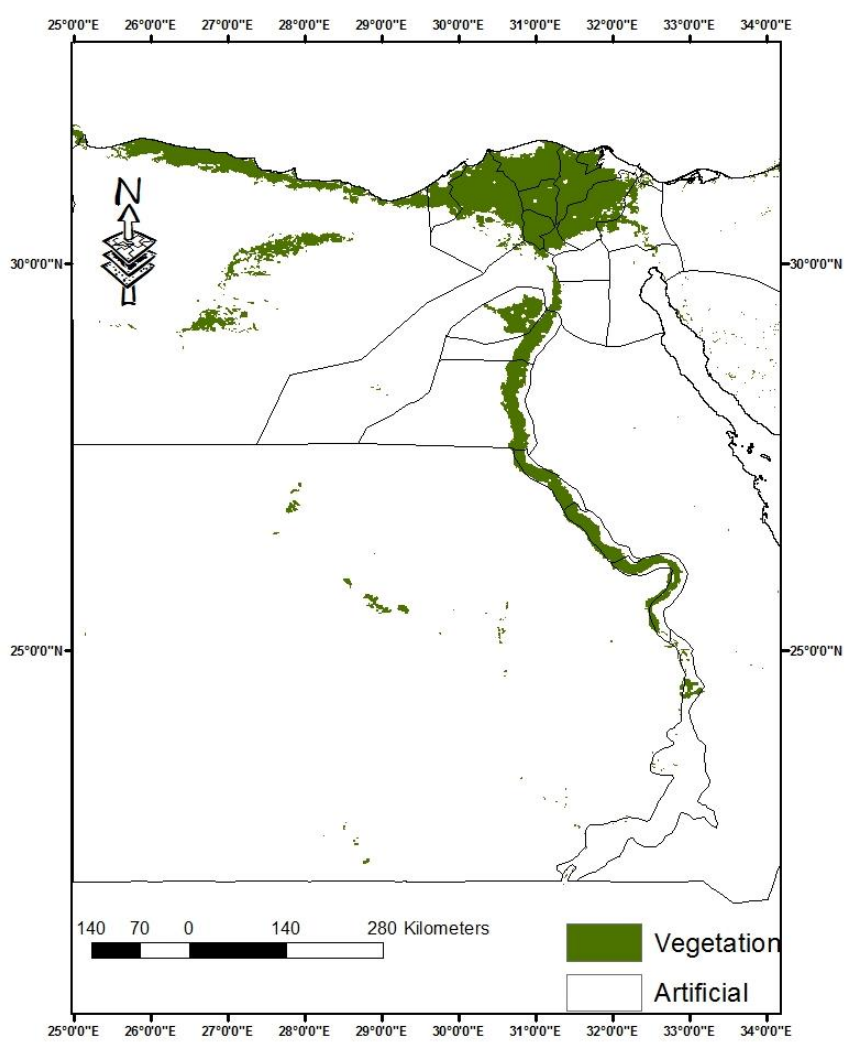

Some random locations were selected within the more suitable regions for apiculture as presented in Table 3. The locations were selected randomly mainly from regions with desert nature at three different governorates; Matruh, Shamal Sina (North Sina), and El-Bahar El-Ahmar (Red Sea).

Table 3. Longitude (Long.) and Latitude (Lat.) of selected locations within more suitable areas at Matruh, Shamal Sina, and El-Bahar El-Ahmar governorates.

\begin{tabular}{|c|c|c|c|}
\hline \multirow[t]{2}{*}{ Point } & \multicolumn{3}{|c|}{ Location (coordinates D.D.) } \\
\hline & Matruh & Shamal Sina & El-Bahar El-Ahmar \\
\hline \multirow[t]{2}{*}{ A } & Long. 26.418 & Long. 33.806 & Long. 33.083 \\
\hline & Lat. 31.404 & Lat. 31.116 & Lat. 25.157 \\
\hline \multirow[t]{2}{*}{ B } & Long. 27.66 & Long. 34.157 & Long. 33.899 \\
\hline & Lat. 29.856 & Lat. 30.62 & Lat. 26.569 \\
\hline \multirow[t]{2}{*}{$\mathrm{C}$} & Long. 25.878 & Long. 34.318 & Long. 34.337 \\
\hline & Lat. 29.184 & Lat. 30.021 & Lat. 24.537 \\
\hline
\end{tabular}

The selected locations within the more suitable areas at El-Bahar El-Ahmar governorate (Red Sea governorate) shows that the locations are typically existed in desert lands but relatively near to cultivated areas (Figure 4). These locations based on the used model have good climatic conditions, and even lands. According to the suitability map, the surrounded areas to these locations are either more suitable or suitable to beekeeping, while lands with harsh nature were classified as unsuitable. It could be said that the Google Earth map is in line with the suitability map obtained from the spatial analysis, suggesting that the used model is suitable to identify potential apiary locations. 

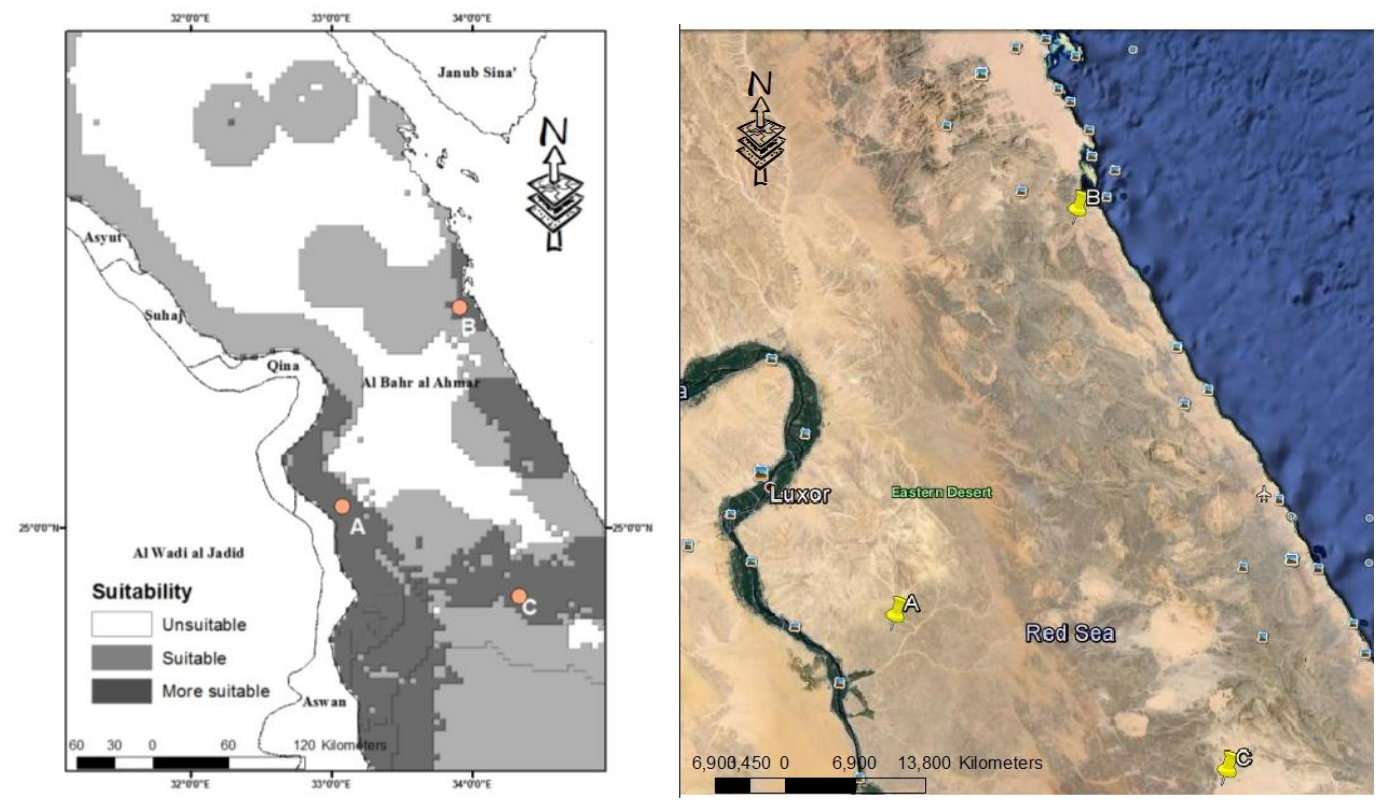

Figure 4. Three randomly sleceted locations; A, B, and C within the more suitable areas at ElBahar El-Ahmar governorate (Red Sea governorate). Left: Suitability map obtained from the GIS, and Right: Real map from Google Earth shows the selected locations marked with yellow land marks.

The selected locations at Matruh governorate within the more suitable areas (Figure 5) are located close to cultivated areas except location (A) which was located approximately in desert area with very few plants. As said with the previous locations at Red Sea governorate, these locations have the more suitable conditions to beekeeping. The close view to location (C) presented in Figure 6, confirms that this location in very close to Siwa oasis (an oasis with good climate and vegetation). It could be said that although the desert nature of most areas, still beekeeping is suitable to be practiced in them. Accordingly, Abou-Shaara (2013b) found most areas at El-Behera governorate were suitable to keep honey bee colonies during winter including desert areas.
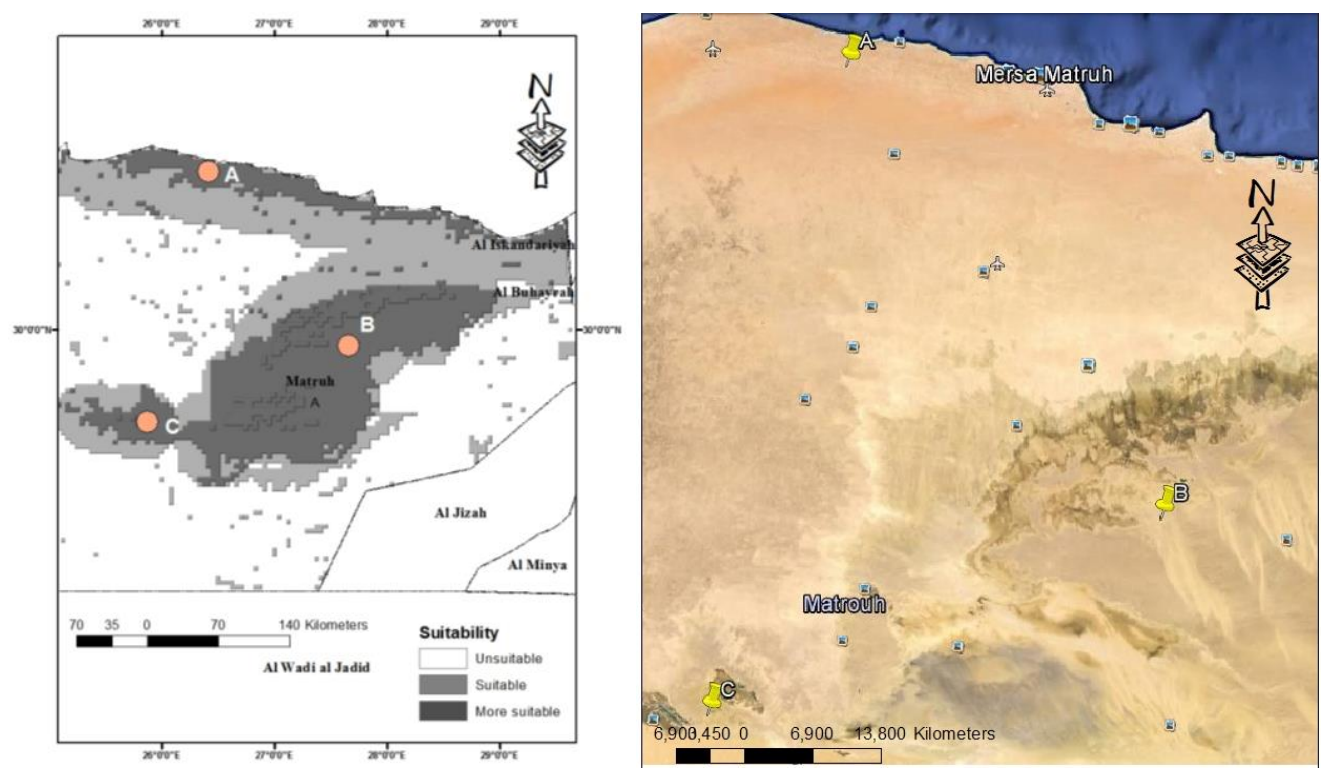

Figure 5. Randomly selected locations; $\mathrm{A}, \mathrm{B}$, and $\mathrm{C}$ within more suitable areas at Matruh governorate. Left: Selected locations on the suitability map, and Right: selected locations as yellow land marks on Google Earth map. 


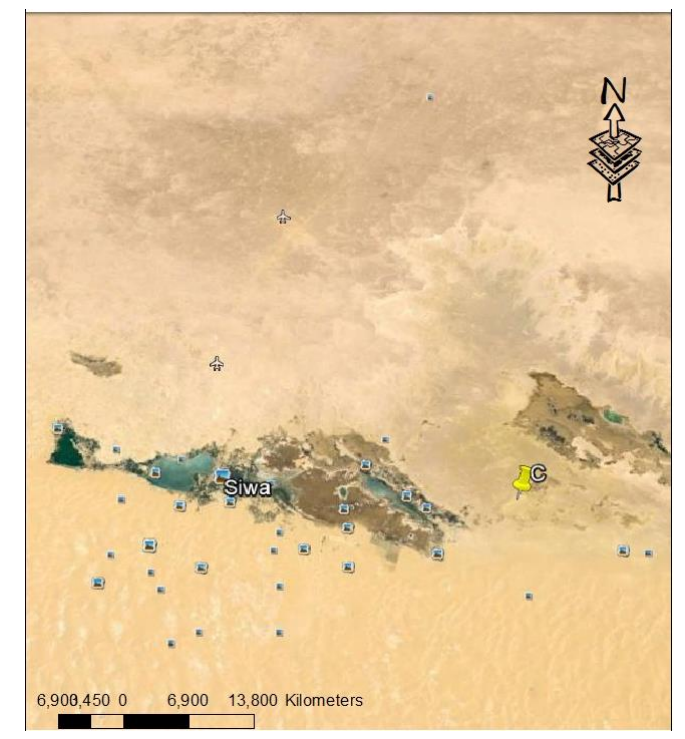

Figure 6. Close view to location $\mathrm{C}$ and Siwa oasis.

Similarly to the previous two governorates, the randomly selected locations are existed in areas which can be considered as more suitable to apiculture (Figure 7). As shown in Figure 8, location A is existed in cultivated areas and near to Arish city that supports the validation of the used model. It is clear that the more suitable areas are very small likely due to the desert nature of this governorate. The areas classified as suitable are relatively large due to small cultivated areas, and the general harsh conditions of this governorate. Areas classified as unsuitable could be explained mainly due to the unsuitable land slope and the absence of cultivated plants.
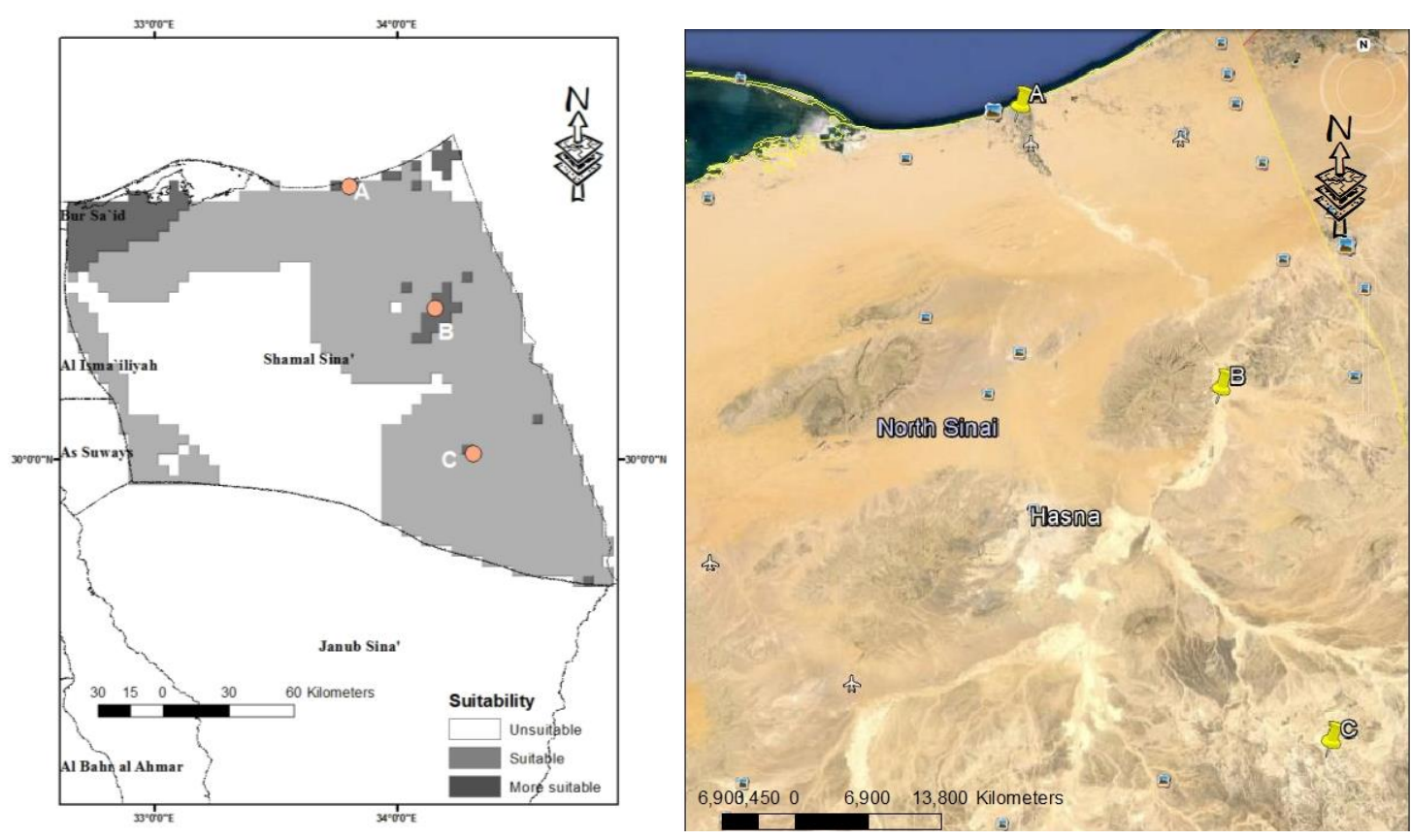

Figure 7. Randomly selected locations; A, B, and C within the more suitable areas at North Sina governorate. Left: suitability map with selected locations, Right: Selected locations marked with yellow land marks on Google Earth map. 


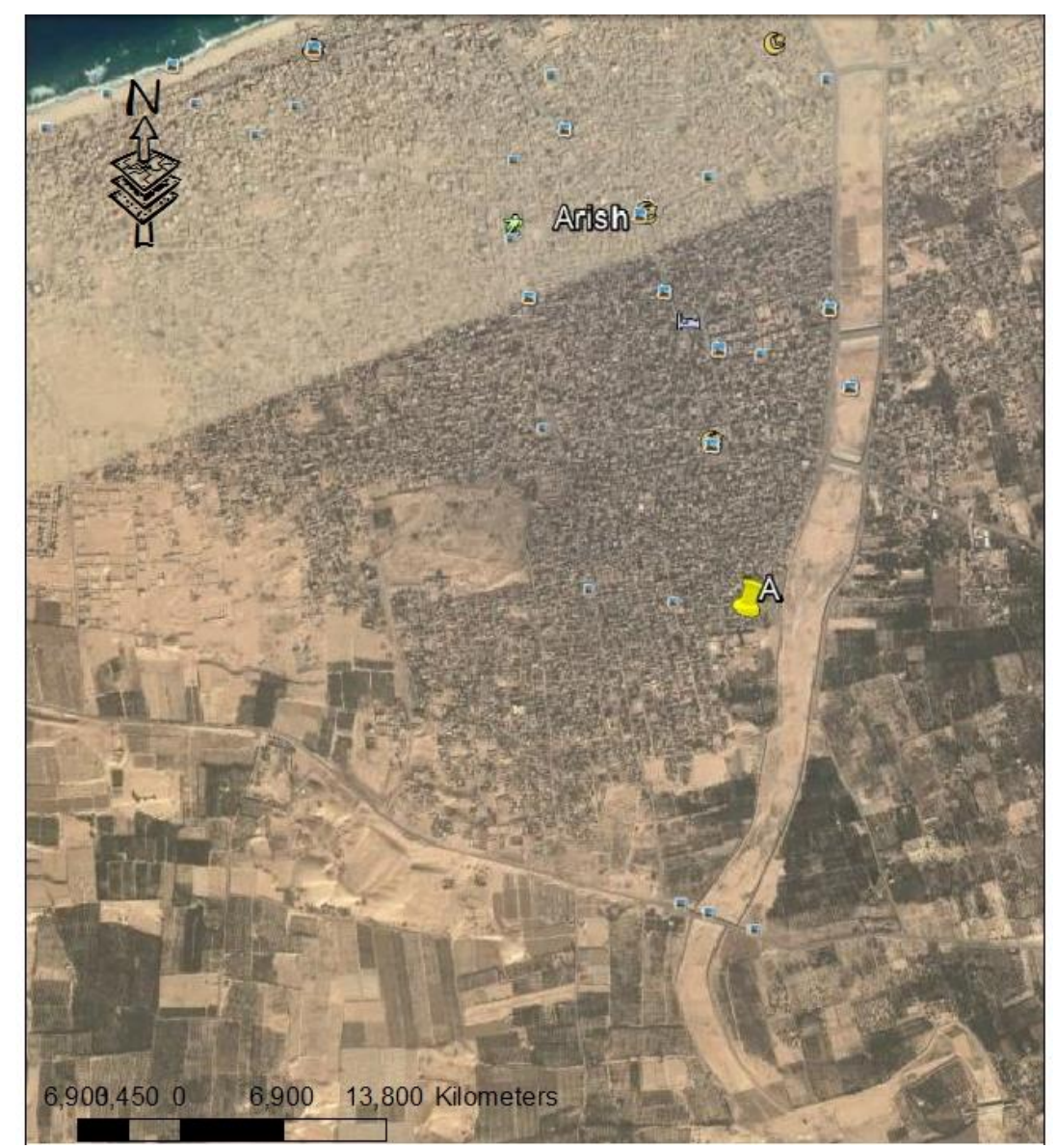

Figure 8. Location (A) is close to cultivated areas and Arish city.

\subsection{Land suitability to apiculture in the future (2070)}

Figure 9. shows the variations between current and future suitability maps. It is clear that most Upper Egypt will be less suitable to beekeeping than nowadays, and some areas will be unsuitable to apiculture. That could be explained by climate change, and mainly heat stress on honey bee colonies at these regions. Similarly, suitability of regions around the Nile River to apiculture will be impacted by future conditions, and will be with less suitable to apiculture. The impact on north Egypt will not be huge, however some regions currently classified as unsuitable will be suitable to apiculture in the future. Additionally, it has been found that land reclamation at North West Egypt is done actively (Abou-Shaara 2013a), that supports the expectation that apiculture will be widely done at north Egypt in the future than currently. It could also be said that climatic conditions in north Egypt will be somewhat in favor to apiculture rather than current conditions, including desert areas. It is expected that protecting honey bee colonies from thermal stress in the future will be necessary. Using modified beehives to keep honey bee colonies in the future could be considered to be a correct way, as done previously by Abou-Shaara et al. (2013c) in Saudi Arabia, they used different modified beehives to protect honey bee colonies during summer. 


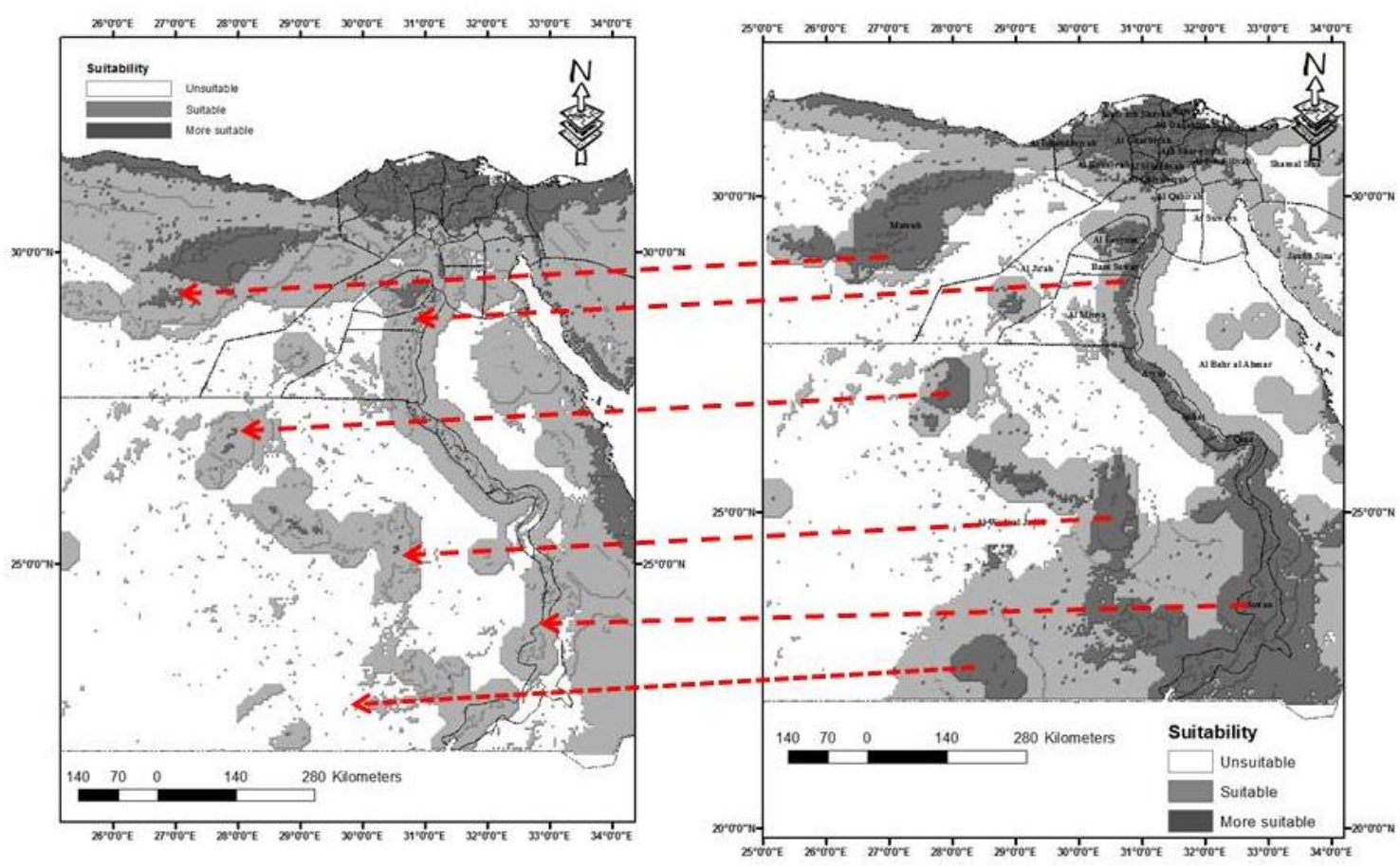

Figure 9. Future suitability map (left) and current suitability map (right). Areas with clear variations were denoted by red arrows.

\section{Conclusion}

According to the suitability analysis to apiculture, Egypt map was classified into three categories; unsuitable, suitable or more suitable. Most areas were classified as suitable or more suitable while the very harsh ones were classified as unsuitable. The results reflect the high potential of using land at different governorates to apiculture. It could be expected that land suitability to apiculture will be greatly impacted by future conditions especially at upper Egypt, and more areas in the north will be suitable to apicuture. Beekeepers in the near future may had to change their current apiary locations. Searching for suitable procedures to protect honey bee colonies from thermal stress in the future are strongly recommended.

\section{References}

Abou-Shaara, HF 2013a 'Using geographical information system (GIS) and satellite remote sensing for understanding the impacts of land cover on apiculture over time. International Journal of Remote Sensing Applications, 3 (4): 171-174. doi: 10.14355/ijrsa.2013.0304.01

Abou-Shaara, HF 2013b 'Wintering map for honey bee colonies in El-Behera governorate, Egypt by using geographical information system (GIS). Journal of Applied Sciences and Environmental Management, 17 (3): 403-408. doi: 10.4314/jasem.v17i3.9

Abou-Shaara, HF 2013c 'A morphometry map and a new method for honey bee morphometric analysis by using the ArcGIS. Arthropods, 2(4): 189-199.

Abou-Shaara, HF 2014 'The foraging behaviour of honey bees, Apis mellifera: a review. Veterinarni Medicina, 59 (1): 1-10.

Abou-Shaara, HF, Al-Ghamdi, AA, \& Mohamed AA 2013a 'Identifying possible regions for using modified beehives in Saudi Arabia using a geographical information system (GIS). Journal of Agricultural Technology, 9 (7): 1937-1945.

Abou-Shaara, HF, Al-Ghamdi, AA, \& Mohamed AA 2013b 'A suitability map for keeping honey bees under harsh environmental conditions using geographical information system. World Applied Sciences Journal, 22 (8): 1099-1105. doi: 10.5829 /idosi.wasj.2013.22.08.7384

Abou-Shaara, HF, Al-Ghamdi, AA, \& Mohamed AA 2013c 'Honey bee colonies performance enhance by newly modified beehives. Journal of Apicultural Science, 57 (2): 45-57. doi: 10.2478/jas-2013-0016 
Al-Qarni AS 2006 'Tolerance of summer temperature in imported and indigenous honeybee Apis mellifera L. races in central Saudi Arabia. Saudi Journal of Biological Sciences, 13: 123-127.

Amiri F, \& Shariff ABM 2012 'Application of geographic information systems in landuse suitability evaluation for beekeeping: A case study of Vahregan watershed (Iran). African Journal of Agricultural Research, 7(1):8997. doi: $10.5897 /$ ajar10.1037

Amiri F, Shariff ABM, \& Arekhi S 2011 'An approach for rangeland suitability analysis to apiculture planning in Gharah Aghach region, Isfahan-Iran. World Applied Sciences Journal, 12 (7): 962-972.

Blazyte-Cereskiene, L, Vaitkeviciene G, Venskutonyte S, \& Buda V 2010 'Honey bee foraging in spring oilseed rape crops under high ambient temperature conditions. Zemdirbyste-Agriculture, 97: 61-70.

Coulson, RN, Pinto MA, Tchakerian MD, Baum KA, Rubink WL, \& Johnston JS 2005 'Feral honey bees in pine forest landscapes of east Texas. Forest ecology and management, 215: 91-102. doi: $\underline{10.1016 / j . f o r e c o .2005 .05 .005}$

Huang, Z 2012 'Pollen nutrition affects honey bee stress resistance. Terrestrial Arthropod Reviews, 5:175-189. doi: $10.1163 / 187498312 \times 639568$

Hussein, MH 2001 'Beekeeping in africa: I- north, east, north-east and west African countries. Proc. 37th Int. Apic. Congr., 28 Oct.-1 Nov., Durban, South Africa.

Joshi, NC, \& Joshi PC 2010 'Foraging behaviour of Apis spp. on apple flowers in a subtropical environment. New York Science Journal, 3: 71-76.

Le Conte, Y, \& Navajas M 2008 'Climate change: impact on honey bee populations and diseases. Revue scientifique et technique, 27 (2), 499-510.

Myung-Hee, J, Joon-Bum K, \& Seong-Baek B 2001 'Selection technique for honey Plant complex area using landsat image and GIS. The 22nd Asian Conference on Remote Sensing, 5-9 November, Singapore.

Nicolson, SW 2008 'Water homeostasis in bees, with the emphasis on sociality. Journal of Experimental Biology, 212: 429-434. doi: 10.1242/jeb.022343

Petz, M, Stabentheiner A, \& Crailsheim K 2004 'Respiration of individual honeybee larvae in relation to age and ambient temperature. Journal of Comparative Physiology B, 174: 511-518. doi: 10.1007/s00360-004-0439-Z

Rader, R, Reilly J, Bartomeus I, \& Winfree R 2013 'Native bees buffer the negative impact of climate warming on honey bee pollination of watermelon crops. Global Change Biology, 19 (10): 3103-3110. doi: $\underline{0.1111 / g c b .12264}$

Tautz, J, Maier S, Groh C, Rossler W, \& Brockmann A 2003 'Behavioral performance in adult honey bees is influenced by the temperature experienced during their pupal development. Proceedings of the National Academy of Sciences of the United States of America USA 100: 7343-7347. doi: 10.1073/pnas.1232346100

Yoruk, A, \& Sahinler N 2013 'Potential effects of global warming on the honey bee. Uludag Bee Journal, 13 (2): 79-87.

Zaitoun S, \& Vorwohl G 2003 'Major pollen plant species in relation to honeybees' activity in the Jordanian desert area. International Journal of Agriculture \& Biology, 5(4): 411-415. 